\title{
PHYSIOLOGICAL ATTRIBUTES OF TRANSPLANT AMAN RICE (cv. BRRI dhan52) AS AFFECTED BY TILLER SEEDLINGS AND UREA SUPER GRANULES
}

\author{
S. K. Paul ${ }^{*}$ K. S. Rahman and M. A. R. Sarkar \\ Department of Agronomy, Bangladesh Agricultural University \\ Mymensingh-2202, Bangladesh
}

\begin{abstract}
The experiment was conducted at the Agronomy Field Laboratory, Bangladesh Agricultural University, Mymensingh, Bangladesh to investigate the effect of age of tiller seedlings, number of tiller seedlings hill-1 and application of urea super granules (USG) on some physiological attributes of transplant Aman rice cv. BRRI dhan52. The experiment consisted of two ages of tiller seedlings viz. 25- and 35-day old, three levels of tiller seedlings hill-1 viz.1, 3 and 5 seedlings hill-1 and three USG levels viz. $0,1.8 \mathrm{~g}$ and $2.7 \mathrm{~g}$ USG per four hills in every alternate row. The experiment was laid out in a randomized complete block design with three replications. The effect of age of tiller seedlings, number of tiller seedlings hill-1 and USG application were significant on crop growth rate (CGR), relative growth rate (RGR), net assimilation rate (NAR) and leaf area index (LAI). The highest CGR and RGR were found by transplanting 35-day old tiller seedlings during the period at 15-30 and 60-75 DAT when 5 tiller seedlings hill ${ }^{-1}$ were transplanted. The highest NAR was observed at 60-75 DAT with transplanting 5 tiller seedlings hill-1 and the lowest one was recorded at 30-45 DAT. The highest LAI was found at 35-day old tiller seedlings during the period at 60 and 75 DAT when 5 tiller seedlings hill-1 were transplanted. CGR and RGR were found highest by applying $1.8 \mathrm{~g} \mathrm{USG}$ at 45-60 and 60-75 DAT while NAR was the highest with application of 2.7g USG at 60-75 DAT and lowest one was found in control (0 $\mathrm{g}$ USG) at 45-60 and 60-75 DAT. The highest LAI was found by applying $1.8 \mathrm{~g}$ USG at 15, 30, 45 and 60 DAT and the lowest one was found at 60 DAT in control and at 15, 30 and 45 DAT when $2.7 \mathrm{~g}$ USG was applied. The highest LAI and CGR were found in older tiller seedlings (35- day old) by transplanting five tiller seedlings hill-1 fertilized with $1.8 \mathrm{~g}$ USG whereas the highest RGR and NAR were obtained in younger tiller seedlings (25-day old) by transplanting single tiller seedling hill-1 fertilized with $1.8 \mathrm{~g}$ USG per four hills of every alternate row.
\end{abstract}

Key Words: Physiological attributes, Tiller seedlings, USG, Transplant Aman rice

\section{INTRODUCTION}

Crop damage due to early or late flood is a very common feature in Bangladesh. It affects transplant Aman rice during July to December in Kharif season. Farmers cannot re-transplant

*Corresponding author (Email: skpaull@gmail.com) 
the affected land due to unavailability of seedlings in flood affected areas. Thus scarcity of seedlings is a great problem in this situation. Re-transplantation of separated tiller from an unaffected Aman crop and subsequent management practices could be a remedy to overcome this loss of transplant Aman rice. Rice has unique ability to tiller profusely as each leaf axils has the potential to produce a tiller (Langer, 1979). In rice, many of the late tillers do not produce grain due to higher population (Nishikawa and Hanada, 1951 and Hanada, 1979). Removal of excessive tillers from the mother hill at early stage could help better development for remaining tillers. This technique of transplanting of separated tillers may be a promising alternative for growing post-flood transplant Aman rice (Mridha et al., 1991; Siddique et al., 1991). Among the growth parameters leaf area index (LAI) is a dimensionless variable and was first defined as the total one-sided area of photosynthetic tissue per unit ground surface area (Inge et al., 2004). LAI is the component of crop that accounts for the ability of the crop to capture light energy and is critical to understand the function of many crop management practices. Leaf area index can have importance in many areas of agronomy and crop production through its influence: light interception, crop growth, weed control, crop-weed competition, crop water use and soil erosion (Welles, 1990; Sonnetag et al., 2007). NAR measures the mean photosynthetic efficiency of leaves in a crop community. The integration of weight and leaf area measurement over time provides value that is highly useful for studying the growth of crops (Shipley, 2006). Patterson (1982) stated that relative growth rate (RGR), net assimilation rate (NAR) and leaf area ratio (LAR) are good measures of solar reduction capture during growth with NAR and LAR for an individual plant and LAI for population helping to explain differences in RGR. Samba et al. (2003) found that interception of PAR (photosynthetically active radiation) is closely followed by LAI. Reduced NAR interception causes reduction of the RGR, NAR and LAR. Mansab et al. (2003) reported that for maximum crop growth, enough leaves must be present in the canopy to intercept most of the incident NAR. Therefore, growth is often expressed on a leaf-area basis. According to Tsuni and Fujise (1965), there is a linear relationship between leaf-area and net assimilation. The present study was undertaken to analyse different growth parameters viz. crop growth rate (CGR), relative growth rate (RGR), net assimilation rate (NAR) and leaf area index (LAI) when separated tillers were used as planting materials as an alternative of nursery seedling of transplant Aman rice.

\section{MATERIALS AND METHODS}

A field experiment was conducted at the Agronomy Field Laboratory, Bangladesh Agricultural University, Mymensingh, Bangladesh. The land was medium high with sandy loam texture having $\mathrm{pH}$ 6.4. BRRI dhan52, a high yielding modern rice variety of transplant Aman rice, developed by the Bangladesh Rice Research Institute, was used as the test crop. The experiment comprised two ages of tiller seedlings viz. 25 and 35-day old (tillers were separated manually from previously grown mother crop at 25 and 35 days after transplanting), three levels of tiller seedling hill- ${ }^{-1}$ viz.1, 3 and 5 seedlings hill- $^{-1}$ and three USG levels viz. $0,1.8 \mathrm{~g}$ and $2.7 \mathrm{~g}$ USG per four hills in every alternate row. There were 18 treatments combinations. The experiment was laid out in a randomized complete block design with three replications. Each block was divided into 18 unit plots where 18 treatment combinations were allocated at random. There were 54 unit plots in the experiment. The 
size of unit plot was $4.0 \mathrm{~m} \times 2.5 \mathrm{~m}$. The experimental plots were fertilized with triple super phosphate, muriate of potash, gypsum and zinc sulphate @ 100, 70, 60, 10 kg ha-1. The entire amounts of triple super phosphate, muriate of potash, gypsum and zinc sulphate were applied at final land preparation. Nitrogen was applied according to experimental specification in the form of Urea Super Granules (USG) per four hills in every alternate row at 10 days after transplanting. Physiological attributes such as LAI, CGR, RGR and NAR were calculated by following standard formulae (Radford, 1967 and Hunt, 1978) as shown below:

Leaf area index (LAI): The leaf area was measured by an automatic leaf area meter (Type AAN-7, Hayashi Dam Ko Co., Japan). LAI was calculated as the ratio of total leaf area and total ground area of the sample as described by Hunt (1978). The formula was also expressed by Yoshida (1981).

$$
\mathrm{LAI}=\frac{\mathrm{LA}}{\mathrm{P}}
$$

Where, $\mathrm{LA}=$ Total leaf area of the leaves of all the sampled plants $\left(\mathrm{m}^{2}\right)$

$\mathrm{P}=$ Area of the ground surface covered by the plant $\left(\mathrm{m}^{2}\right)$

Crop growth rate (CGR): Increase of materials per unit of time.

$$
\text { CGR } \left.=\frac{W_{2}-W 1}{T_{2}-T_{1}} \text { (mg day }-1 \text { hill }-1\right)
$$

Relative growth rate (RGR): Increase of plant materials per unit of plant materials per unit of time.

$$
\text { RGR }=\frac{\operatorname{LnW}_{2}-\operatorname{Ln} W_{1}}{T_{2}-T_{1}}(\text { mg day }-1 \text { hill }-1)
$$

Net assimilation rate (NAR): Increasing of plant materials per unit of assimilatory material per unit of time.

$$
\mathrm{NAR}=\frac{W_{2}-W_{1}}{L A_{2}-L A_{1}} \times \frac{L n L A_{2}-L n L A_{1}}{T_{2}-T_{1}}
$$




$$
\begin{aligned}
& \frac{W_{2}-W_{1}}{T_{2}-T_{1}} \times \frac{L n L A_{2}-L n L A_{1}}{L A_{2}-L A_{1}} \\
& =\text { CGR } \times \frac{L n L A_{2}-L n L A_{1}}{L A_{2}-L A_{1}}\left(\mathrm{gcm}^{-2} \text { day }^{-1}\right)
\end{aligned}
$$

Meanings of symbols used in the above formulae are given below:

$$
\begin{aligned}
& \mathrm{W}_{1}=\text { Total dry matter hill-1 at time } T_{1} \\
& \mathrm{~W}_{2}=\text { Total dry weight hill-1 at time } T_{2} \\
& \text { Ln }=\text { Natural logarithm } \\
& \mathrm{LA}=\text { Leaf area } \\
& \mathrm{P}=\text { Ground area } \\
& \mathrm{LA}_{1}=\text { Leaf area at time } \mathrm{T}_{1} \\
& \mathrm{LA}_{2}=\text { Leaf area at time } T_{2}
\end{aligned}
$$

\section{RESULTS AND DISCUSSION}

\section{Leaf area index (LAI)}

Leaf area index was significantly affected by age of tiller seedlings, number of tiller seedlings hill-1 and application of USG. At 60 and 75 DAT the highest LAI was obtained by transplanting 35-day old tiller seedlings at all dates of observations. LAI was increased with increasing the age of tiller seedlings (Table 1). The highest LAI was obtained at 45 DAT when 5 tiller seedlings hill-1 were transplanted and the lowest LAI was found during the period 30 DAT when 1 tiller seedling hill ${ }^{-1}$ was transplanted (Table 1). LAI was significantly affected by USG application during the period of 15, 30, 45 and 60 DAT. The highest LAI was found at 60 DAT when 1.8g USG was applied and the lowest LAI was found at 15 DAT when 2.7g USG was applied (Table 1). Increased plant density significantly increased crop growth rate (CGR) during early stage and reduced the net assimilation rate (NAR) and CGR during later part of crop growth. Higher CGR at vegetative stage originated from which high leaf area index (LAI) and that CGR at reproductive and ripening stages was controlled by NAR (Sarkar et al., 2002). Leaf area index was significantly influenced by the interaction between age of tiller seedlings, number of tiller seedlings hill-1 ${ }^{-1}$ and USG application within the period of 30 and 45 DAT among the dates of sampling (Table 2). At 30 DAT the highest LAI was found in 35-day old tiller seedling by transplanting 3 tiller seedlings hill-1 fertilized with 1.8g USG and the lowest LAI was found in 25-day old tiller seedlings by transplanting 1 tiller seedling hill-1 with the application of $1.8 \mathrm{~g}$ USG. At 45 DAT the highest LAI was found in 35-day old tiller seedling by transplanting 5 tiller seedlings hill-1 fertilized with $1.8 \mathrm{~g}$ USG and the lowest LAI was found in 35-day old tiller seedlings by transplanting 1 tiller seedling hill-1 fertilized with $2.7 \mathrm{~g}$ USG (Table 2). 
Table 1. Effect of age of tiller seedlings, number of tiller seedlings hill-1 and USG application on Leaf area index

\begin{tabular}{c|c|c|c|c|c}
\hline & \multicolumn{5}{|c}{ Leaf area index (LAI) } \\
\cline { 2 - 6 } & \multicolumn{5}{c}{ Days after transplanting } \\
\cline { 2 - 6 } & $\mathbf{1 5}$ & $\mathbf{3 0}$ & $\mathbf{4 5}$ & $\mathbf{6 0}$ & $\mathbf{7 5}$ \\
\hline Age of tiller seedlings (days) & 1.76 & 2.59 & 3.02 & 4.89 & 5.87 \\
25 & 1.89 & 2.97 & 3.33 & 5.66 & 7.09 \\
35 & & & & & \\
No. of tiller seedlings hill-1 & 1.55 & $1.90^{\mathrm{c}}$ & $2.80^{\mathrm{c}}$ & 5.10 & 5.90 \\
1 & 1.75 & $3.19^{\mathrm{b}}$ & $3.68^{\mathrm{b}}$ & 4.79 & 5.26 \\
3 & 1.18 & $3.55^{\mathrm{a}}$ & $4.23^{\mathrm{a}}$ & 5.83 & 6.15 \\
5 & & & & & \\
0 & $1.91^{\mathrm{ab}}$ & $2.89^{\mathrm{ab}}$ & $4.21^{\mathrm{ab}}$ & $4.64^{\mathrm{b}}$ & 6.09 \\
USG application $(\mathrm{g})$ & $1.98^{\mathrm{a}}$ & $3.10^{\mathrm{a}}$ & $4.50^{\mathrm{a}}$ & $5.81^{\mathrm{a}}$ & 7.11 \\
1.8 & $1.59^{\mathrm{b}}$ & $2.36^{\mathrm{b}}$ & $3.81^{\mathrm{b}}$ & $5.37^{\mathrm{b}}$ & 6.70 \\
\hline
\end{tabular}

Figures in column under each factor of treatment having the same letter or without letter do not differ significantly whereas figures with dissimilar letter(s) differ significantly as per DMRT

Table 2. Interaction between of age of tiller seedlings, number of tiller seedlings hill-1 and USG application on leaf area index (LAI)

\begin{tabular}{|c|c|c|c|c|c|c|c|}
\hline \multirow{3}{*}{$\begin{array}{c}\text { Age of tiller } \\
\text { seedlings (days) }\end{array}$} & \multirow{3}{*}{$\begin{array}{l}\text { Number of tiller } \\
\text { seedlings hill-1 }\end{array}$} & \multirow{3}{*}{$\begin{array}{c}\text { USG } \\
\text { application } \\
\text { (g) }\end{array}$} & \multicolumn{5}{|c|}{ Leaf area index (LAI) } \\
\hline & & & \multicolumn{5}{|c|}{ Days after transplanting } \\
\hline & & & 15 & 30 & 45 & 60 & 75 \\
\hline \multirow[t]{9}{*}{25} & 1 & 0 & 2.34 & $2.72^{c-f}$ & 4.13 de & 5.46 & 6.36 \\
\hline & & 1.8 & 1.21 & $2.23^{f}$ & $3.20^{\mathrm{f}}$ & 4.03 & 5.46 \\
\hline & & 2.7 & 1.28 & $2.24^{\mathrm{f}}$ & $3.54^{\mathrm{f}}$ & 4.08 & 5.10 \\
\hline & 3 & 0 & 1.26 & $2.52 \mathrm{def}$ & $3.17^{\mathrm{f}}$ & 4.85 & 5.43 \\
\hline & & 1.8 & 2.23 & $3.40^{\mathrm{bc}}$ & $4.82^{\mathrm{bcd}}$ & 5.51 & 6.41 \\
\hline & & 2.7 & 1.32 & $2.70 \mathrm{def}$ & $3.91^{\mathrm{ef}}$ & 4.06 & 5.45 \\
\hline & 5 & 0 & 2.17 & $3.40^{\mathrm{bc}}$ & $4.99 \mathrm{bcd}$ & 5.70 & 6.11 \\
\hline & & 1.8 & 2.29 & $3.73^{\mathrm{ab}}$ & $5.32^{\mathrm{ab}}$ & 6.07 & 7.55 \\
\hline & & 2.7 & 1.75 & $3.75^{\mathrm{abc}}$ & $4.76^{\mathrm{bc}}$ & 5.16 & 6.79 \\
\hline \multirow[t]{9}{*}{35} & 1 & 0 & 2.04 & $3.51 \mathrm{def}$ & $3.46^{\mathrm{f}}$ & 4.32 & 5.67 \\
\hline & & 1.8 & 1.29 & $3.52 \mathrm{def}$ & $3.92^{\mathrm{ef}}$ & 4.48 & 5.16 \\
\hline & & 2.7 & 1.14 & $3.41^{\mathrm{ef}}$ & $3.57^{f}$ & 4.80 & 5.21 \\
\hline & 3 & 0 & 1.74 & $3.85^{\mathrm{abc}}$ & $5.28 \mathrm{bcd}$ & 6.67 & 7.02 \\
\hline & & 1.8 & 2.30 & $4.22^{\mathrm{a}}$ & $5.15^{b c d}$ & 6.85 & 7.83 \\
\hline & & 2.7 & 1.62 & $3.00^{b-e}$ & $4.33^{\mathrm{d}}$ & 5.80 & 6.39 \\
\hline & 5 & 0 & 1.90 & $2.97 \mathrm{~b}-\mathrm{e}$ & $4.34^{\mathrm{d}}$ & 5.85 & 6.93 \\
\hline & & 1.8 & 2.57 & 3.37abc & $6.20^{\mathrm{a}}$ & 7.20 & 7.94 \\
\hline & & 2.7 & 2.42 & $3.08^{\mathrm{bcd}}$ & $4.72^{\mathrm{cd}}$ & 5.31 & 6.28 \\
\hline
\end{tabular}

Figures in column under each factor of treatment having the same letter or without letter do not differ significantly whereas figures with dissimilar letter(s) differ significantly as per DMRT 


\section{Crop growth rate (CGR)}

Crop growth rate was significantly affected by age of tiller seedlings during the period of 15-30 and 60-75 days after transplanting (DAT). Comparatively high CGR was found by transplanting 35-days old tiller seedlings during the period of 60-75 DAT and it was higher during the period of 60-75 DAT due to transplanting of 25-day old tiller seedlings. The lowest CGR was observed during the period of 15-30 DAT by transplanting 25-day old tiller seedlings while CGR was lower during the period of 15-30 DAT by transplanting 35-day old tiller seedlings. The CGR of both ages of tiller seedlings attained peak within the period of 45-60 DAT. Crop growth rate changed with growth and reached maximum at panicle emergence and decreased thereafter (Wilson and Ellis, 1981 and Tanaka, 1983). Similar research findings was also reported by Hossain et al. (2011) (Table 3). Crop growth rate was significantly affected by the number of tiller seedlings hill-1 within the period of 60-70 DAT. The highest CGR was found when 5 tiller seedlings hill-1 ${ }^{-1}$ followed by 3 tiller seedlings hill-1 ${ }^{-}$ The lowest CGR was found when 1 tiller seedling hill-1 ${ }^{-1}$ was transplanted. CGR increased with increasing number of tiller seedlings hill-1 (Table 3 ). Crop growth rate was significantly affected by USG application during the period of 45-60 and 60-75 DAT. Comparatively high CGR was found during the period of 45-60 and 60-75 DAT when 1.8 g USG was applied while CGR was higher during the period of 60-75 DAT when 2.7g USG was applied. The lowest CGR was found during the period of 60-75 DAT when 0g USG was not applied while CGR was lower during the period of 45-60 DAT when $0 \mathrm{~g}$ USG was applied. The CGR attained peak within the period of 60-75 DAT when 1.8g USG was applied (Table 3). CGR changed with growth (Tanaka, 1983) and reached maximum at panicle emergence (Wilson and Ellis, 1981). CGR increased with increasing the number of tiller seedlings hill-1 (Hossain et al., 2011). Crop growth rate was significantly influenced by the interaction among age of tiller seedlings, number of tiller seedlings hill-1 and USG application within the period of 15-30, 45-60 and 60-75 DAT. Within the period 15-30 DAT the highest CGR was found in 35-day old tiller seedling by transplanting 5 tiller seedlings hill-1 ${ }^{-1}$ with the application of USG $1.8 \mathrm{~g}$ and the lowest CGR was found in 25-day old tiller seedlings by transplanting 5 tiller seedlings hill-1 fertilized with $1.8 \mathrm{~g}$ USG. Within the period of 45-60 DAT the highest CGR was found in 35-day old tiller seedlings by transplanting 3 tiller seedlings hill-1 fertilized with 1.8g USG and the lowest CGR was found in 25-day old tiller seedlings by transplanting 1 tiller seedling hill-1 fertilized with USG. Within the period 60-75 DAT, the highest CGR was found in 25-day old tiller seedlings by transplanting 3 tiller seedlings hill-1 fertilized with $2.7 \mathrm{~g}$ and the lowest CGR was found in 25-day old tiller seedlings by transplanting 1 tiller seedling hill-1 ${ }^{-1}$ ithout application of USG (Table 4).

\section{Relative growth rate (RGR)}

Relative growth rate was significantly affected by age of tiller seedlings during the period of 30-45 and 60-75 DAT. Comparatively higher RGR was observed by transplanting 35-days old tiller seedlings during the period of 30-45 and 60-75 DAT. The lowest RGR was observed during the period of 30-45 DAT by transplanting 25-day old tiller seedlings (Table 3). Relative growth rate was significantly affected by number of tiller seedlings hill-1 during the period of 60-75 DAT. The highest RGR was found within the period of 60-75 DAT when 5 tiller seedlings hill-1 were transplanted and the lowest RGR was found within the period of 30-45 DAT when 1 tiller seedling was transplanted hill-1 (Table 3). Relative growth rate was 
significantly affected by USG application during the period of 45-60 and 60-75 DAT. Comparatively higher RGR was found during the period of 45-60 DAT when 1.8g USG was applied while RGR was higher during the period of 45-60 DAT when $2.7 \mathrm{~g}$ USG was applied. The lowest RGR was found during the period of 60-75 DAT while USG was not applied. The RGR attained peak within the period of 45-60 DAT when 1.8g USG was applied. ElZahab et al. (1980) stated that RGR increased steadily during early growth stages and then decreased slowly. Haloi and Baldev (1986) observed higher RGR at initial stage of crop growth. Karim and Siddique (1991) stated that higher RGR was obtained at vegetative phase. RGR increased with increasing the number of tiller seedlings hill-1 (Table 3). Relative growth rate was significantly influenced by the interaction between age of tiller seedlings, number of tiller seedlings hill-1 and USG application within the period of 45-60 DAT. Within the period of 45-60 DAT the highest RGR was found in 25-day old tiller seedlings by transplanting 1 tiller seedling hill-1 and fertilized with $1.8 \mathrm{~g}$ USG and the lowest RGR was found in 25-day old tiller seedling by transplanting 5 tiller seedlings hill-1 with the application of $1.8 \mathrm{~g}$ USG (Table 4).

Table 3. Effect of age of tiller seedlings, number of tiller seedlings hill-1 ${ }^{-1}$ and USG application on crop growth rate (CGR) and relative growth rate (RGR)

\begin{tabular}{|c|c|c|c|c|c|c|c|c|}
\hline & \multirow{2}{*}{\multicolumn{4}{|c|}{$\begin{array}{l}\text { Crop growth rate } \times 10^{-4} \\
\left(\mathrm{mg} \mathrm{day}^{-1} \text { hill- }^{-1}\right) \\
\text { Days after transplanting }\end{array}$}} & \multirow{2}{*}{\multicolumn{4}{|c|}{$\begin{array}{l}\text { Relative growth rate } \times 10^{-4} \\
\left(\mathrm{mg} \mathrm{day}^{-1} \text { hill- }^{-1}\right)\end{array}$}} \\
\hline & & & & & & & & \\
\hline & $15-30$ & $30-45$ & $45-60$ & $60-75$ & $15-30$ & $30-45$ & $45-60$ & $60-75$ \\
\hline \multicolumn{9}{|c|}{ Age of tiller seedlings (days) } \\
\hline 25 & $0.83^{b}$ & 0.63 & 2.25 & $2.14^{\mathrm{b}}$ & 62.46 & $23.80^{\mathrm{b}}$ & 47.53 & $26.28^{b}$ \\
\hline 35 & $0.92^{\mathrm{a}}$ & 0.67 & 2.10 & $2.43^{-}$ & 57.54 & $24.36^{\mathrm{a}}$ & 44.25 & $28.89 a$ \\
\hline \multicolumn{9}{|c|}{ No. of tiller seedlings hill-1 } \\
\hline 1 & 0.76 & 0.64 & 2.22 & $2.00^{c}$ & 61.48 & 26.07 & 48.52 & $24.82^{c}$ \\
\hline 3 & 0.93 & 0.65 & 2.05 & $2.23^{b}$ & 61.37 & 23.85 & 44.17 & $27.64^{\mathrm{b}}$ \\
\hline 5 & 0.94 & 0.65 & 2.26 & $2.63^{a}$ & 57.16 & 22.32 & 44.98 & $30.30^{a}$ \\
\hline \multicolumn{9}{|c|}{ USG application (g) } \\
\hline 0 & 0.88 & 0.65 & $1.90^{\mathrm{b}}$ & $1.86^{c}$ & 54.86 & 23.53 & $40.75^{b}$ & $23.72^{b}$ \\
\hline 1.8 & 0.86 & 0.65 & $2.38^{a}$ & $2.58^{a}$ & 56.60 & 24.08 & $48.96^{a}$ & $29.91^{a}$ \\
\hline 2.7 & 0.89 & 0.65 & $2.24^{\mathrm{ab}}$ & $2.42^{\mathrm{b}}$ & 68.55 & 24.63 & $47.97 \mathrm{a}$ & $29.13^{a}$ \\
\hline
\end{tabular}

Figures in column under each factor of treatment having the same letter or without letter do not differ significantly whereas figures with dissimilar letter(s) differ significantly as per DMRT

\section{Net assimilation rate (NAR)}

Net assimilation rate was not significantly affected by age of tiller seedlings during the period of 15-30, 30-45, 45-60 and 60-75 DAT (Table 5). NAR was significantly affected by number of tiller seedlings hill-1 during the period of 15-30 and 45-60 DAT. The highest NAR was observed within the period of 60-75 DAT when 5 tiller seedlings hill-1 and the lowest NAR was found within the period 30-45 DAT when 5 tiller seedlings were transplanted hill $^{-1}$ (Table 5). NAR is the most important index of mean photosynthetic efficiency of a plant under a particular environment (Haloi and Baldev, 1986). Haloi and Baldev (1986) reported that NAR higher values at initial stage of crop growth but late sowing markedly 
enhanced NAR during reproductive phase. NAR is the most important index of mean photosynthetic efficiency of plant under particular environment; its value is higher at initial stage of crop growth. NAR decreased progressively as the number of tiller seedlings hill-1 increased (Hossain et al., 2011). Net assimilation rate was significantly influenced by the interaction between age of tiller seedlings, number of tiller seedlings hill-1 and USG application within the period of 15-30, 30-45 and 45-60 DAT. Within the period of 15-30 DAT the highest NAR was found in 25-day old tiller seedling by transplanting 1 tiller seedlings hill-1 fertilized with $1.8 \mathrm{~g}$ USG and the lowest NAR were found in 35-day old tiller seedlings by transplanting 5 tiller seedlings hill-1 ${ }^{-1}$ fertilized with $1.8 \mathrm{~g}$ USG. Within the period of 30-45 DAT the highest NAR was found in 25-day old tiller seedling by transplanting 3 tiller seedlings hill-1 under control treatment and the lowest NAR was found in 35-day old tiller seedlings by transplanting 3 tiller seedlings hill-1 under control treatment. Within the period of 45-60 DAT the highest NAR was found in 25-day old tiller seedling by transplanting 1 tiller seedling hill-1 ${ }^{-1}$ fertilized with $1.8 \mathrm{~g}$ USG and the lowest NAR was found in 25-day old tiller seedlings by transplanting 5 tiller seedlings hill-1 ${ }^{-1}$ fertilized with $1.8 \mathrm{~g}$ USG (Table 6).

Table 4. Interaction between of age of tiller seedlings, number of tiller seedlings hill-1 and USG application on crop growth rate (CGR) and relative growth rate (RGR)

\begin{tabular}{|c|c|c|c|c|c|c|c|c|c|c|}
\hline \multirow{3}{*}{$\begin{array}{l}\text { Age of } \\
\text { tiller } \\
\text { seedlings } \\
\text { (days) }\end{array}$} & \multirow{3}{*}{$\begin{array}{l}\text { Number of } \\
\text { tiller } \\
\text { seedlings } \\
\text { hill-1 }^{-1}\end{array}$} & \multirow{3}{*}{$\begin{array}{l}\text { USG } \\
\text { applic } \\
\text { ation } \\
(\mathrm{g})\end{array}$} & \multirow{2}{*}{\multicolumn{4}{|c|}{$\begin{array}{l}\text { Crop growth rate } \times 10^{-4} \\
\left(\mathrm{mg} \mathrm{day}^{-1} \text { hill-1 }^{-1}\right) \\
\text { Days after transplanting }\end{array}$}} & \multirow{2}{*}{\multicolumn{4}{|c|}{$\begin{array}{l}\text { Relative growth rate } \times 10^{-4} \\
\left(\mathrm{mg} \mathrm{day}^{-1} \text { hill- }^{-1}\right)\end{array}$}} \\
\hline & & & & & & & & & & \\
\hline & & & $15-30$ & $30-45$ & $45-60$ & $60-75$ & $15-30$ & $30-45$ & $45-60$ & $60-75$ \\
\hline \multirow[t]{9}{*}{25} & 1 & 0 & $0.56 \mathrm{~cd}$ & 0.58 & $1.12^{\mathrm{h}}$ & $1.05^{\mathrm{d}}$ & 31.25 & 22.85 & $28.57 \mathrm{fg}$ & 19.35 \\
\hline & & 1.8 & $0.75^{b c d}$ & 0.60 & $2.25^{\mathrm{b}-\mathrm{e}}$ & $2.74^{\mathrm{ab}}$ & 56.12 & 25.04 & $68.20^{a}$ & 28.03 \\
\hline & & 2.7 & $1.01^{\mathrm{abc}}$ & 0.60 & $2.50^{\mathrm{bcd}}$ & $2.84^{\mathrm{ab}}$ & 76.83 & 23.02 & $52.45^{\mathrm{bcd}}$ & 32.22 \\
\hline & 3 & 0 & $0.92^{\mathrm{abc}}$ & 0.68 & $1.90^{\mathrm{d}-\mathrm{g}}$ & $1.90^{\mathrm{bcd}}$ & 63.92 & 26.48 & $43.07 \mathrm{c}-\mathrm{f}$ & 25.58 \\
\hline & & 1.8 & $0.82^{\mathrm{a}-\mathrm{d}}$ & 0.65 & $2.06^{c-f}$ & $2.64^{\mathrm{ab}}$ & 51.39 & 24.11 & $44.38^{\mathrm{b}-\mathrm{f}}$ & 32.39 \\
\hline & & 2.7 & $0.78^{\mathrm{a}-\mathrm{d}}$ & 0.60 & $2.72 \mathrm{abc}$ & $2.92^{a}$ & 62.01 & 25.46 & $60.04^{\mathrm{ab}}$ & 32.76 \\
\hline & 5 & 0 & $1.18^{\mathrm{ab}}$ & 0.65 & $2.58^{\mathrm{a}-\mathrm{d}}$ & $2.83^{\mathrm{ab}}$ & 72.39 & 21.06 & $48.34^{\mathrm{bcd}}$ & 30.04 \\
\hline & & 1.8 & $0.40^{\mathrm{d}}$ & 0.72 & $1.27 \mathrm{gh}$ & 2.19abc & 75.41 & 21.43 & $26.50 \mathrm{~g}$ & 29.76 \\
\hline & & 2.7 & $0.98^{a b c}$ & 0.64 & $2.77 \mathrm{abc}$ & $2.74^{\mathrm{ab}}$ & 72.86 & 24.72 & $56.24^{\mathrm{abc}}$ & 29.89 \\
\hline \multirow[t]{9}{*}{35} & 1 & 0 & $0.80^{\mathrm{a}-\mathrm{d}}$ & 0.67 & $1.91^{\mathrm{d}-\mathrm{g}}$ & $1.08^{\mathrm{d}}$ & 60.12 & 27.33 & $44.61^{\mathrm{b}-\mathrm{f}}$ & 15.78 \\
\hline & & 1.8 & $0.72^{\mathrm{bcd}}$ & 0.74 & $2.99 \mathrm{ab}$ & $2.74^{\mathrm{ab}}$ & 54.01 & 30.19 & $60.00^{\mathrm{ab}}$ & 28.98 \\
\hline & & 2.7 & $0.73^{b c d}$ & 0.67 & $1.46^{\text {fgh }}$ & $1.53^{\mathrm{cd}}$ & 90.54 & 27.95 & $37.32^{\mathrm{d}-\mathrm{g}}$ & 24.54 \\
\hline & 3 & 0 & $0.98^{a b c}$ & 0.68 & $1.47 \mathrm{e}-\mathrm{h}$ & $1.42^{\mathrm{cd}}$ & 47.27 & 20.30 & $29.91 \mathrm{efg}$ & 19.23 \\
\hline & & 1.8 & $1.17 \mathrm{ab}$ & 0.63 & $3.34^{\mathrm{a}}$ & $2.57 \mathrm{ab}$ & 80.78 & 21.18 & $45.44^{\text {b-e }}$ & 29.69 \\
\hline & & 2.7 & $0.89 \mathrm{a}-\mathrm{d}$ & 0.68 & $1.88^{\mathrm{d}-\mathrm{g}}$ & $1.94^{\mathrm{a}-\mathrm{d}}$ & 62.83 & 25.55 & $42.19 \mathrm{c}-\mathrm{g}$ & 26.20 \\
\hline & 5 & 0 & $0.86^{\mathrm{a}-\mathrm{d}}$ & 0.64 & $2.43^{\mathrm{bcd}}$ & $2.88^{\mathrm{ab}}$ & 54.22 & 23.15 & $50.01 \mathrm{bcd}$ & 32.34 \\
\hline & & 1.8 & $1.29 \mathrm{a}$ & 0.59 & $2.37 \mathrm{bcd}$ & $2.58^{\mathrm{ab}}$ & 21.89 & 22.50 & $49.22^{\mathrm{bcd}}$ & 30.60 \\
\hline & & 2.7 & $0.94 \mathrm{abc}$ & 0.70 & $2.12^{c-f}$ & $2.55^{\mathrm{ab}}$ & 46.21 & 21.06 & $39.58 \mathrm{~d}-\mathrm{g}$ & 29.16 \\
\hline
\end{tabular}

Figures in column under each factor of treatment having the same letter or without letter do not differ significantly whereas figures with dissimilar letter(s) differ significantly as per DMRT 
Table 5. Effect of age of tiller seedlings, number of tiller seedlings hill-1 ${ }^{-1}$ and USG application on net assimilation rate (NAR)

\begin{tabular}{|c|c|c|c|c|}
\hline & \multicolumn{4}{|c|}{$\begin{array}{l}\text { Net assimilation rate } \times 10^{-4} \\
\qquad\left(\mathrm{~g} \mathrm{~cm}^{-2} \text { day }^{-1}\right)\end{array}$} \\
\hline & \multicolumn{4}{|c|}{ Days after transplanting } \\
\hline & $15-30$ & $30-45$ & $45-60$ & 60-75 \\
\hline \multicolumn{5}{|c|}{ Age of tiller seedlings (days) } \\
\hline 25 & 2.64 & 1.19 & 2.75 & 2.10 \\
\hline 35 & 2.24 & 1.17 & 2.53 & 2.04 \\
\hline \multicolumn{5}{|c|}{ Number of tiller seedling hill-1 } \\
\hline 1 & 2.62 & $1.44^{\mathrm{a}}$ & 2.94 & $1.80^{c}$ \\
\hline 3 & 2.47 & $1.12^{\mathrm{b}}$ & 2.49 & $2.03^{b}$ \\
\hline 5 & 2.23 & $0.99 c$ & 2.49 & $2.37 \mathrm{a}$ \\
\hline \multicolumn{5}{|c|}{ USG application (g) } \\
\hline 0 & 2.39 & 1.17 & 2.37 & 1.80 \\
\hline 1.8 & 2.24 & 1.13 & 2.84 & 2.23 \\
\hline 2.7 & 2.69 & 1.24 & 2.72 & 2.17 \\
\hline
\end{tabular}

Figures in column under each factor of treatment having the same letter or without letter do not differ significantly whereas figures with dissimilar letter(s) differ significantly as per DMRT

Table 6. Interaction between of age of tiller seedlings, number of tiller seedlings hill-1 and USG application on net assimilation rate (NAR)

\begin{tabular}{|c|c|c|c|c|c|c|}
\hline \multirow[t]{3}{*}{$\begin{array}{c}\text { Age of tiller } \\
\text { seedlings (days) }\end{array}$} & \multirow[t]{3}{*}{$\begin{array}{l}\text { Number of tiller } \\
\text { seedlings hill-1 }\end{array}$} & \multirow[t]{3}{*}{$\begin{array}{c}\text { USG application } \\
\text { (g) }\end{array}$} & \multicolumn{4}{|c|}{$\begin{array}{l}\text { Net assimilation rate } \times 10^{-4} \\
\left(\mathrm{~g} \mathrm{~cm}^{-2} \text { day }^{-1}\right)\end{array}$} \\
\hline & & & \multicolumn{4}{|c|}{ Days after transplanting } \\
\hline & & & $15-30$ & $30-45$ & $45-60$ & $60-75$ \\
\hline \multirow[t]{9}{*}{25} & 1 & 0 & $1.46^{\mathrm{cd}}$ & 0.99de & $1.37 \mathrm{gh}$ & 0.96 \\
\hline & & 1.8 & $2.81^{\mathrm{abc}}$ & $1.49 a b c$ & $4.95^{\mathrm{a}}$ & 2.86 \\
\hline & & 2.7 & $3.74^{\mathrm{a}}$ & $1.46^{\mathrm{abc}}$ & $3.29 \mathrm{bcd}$ & 2.57 \\
\hline & 3 & 0 & 3.17ab & $1.63^{a}$ & 2.99b-e & 2.10 \\
\hline & & 1.8 & $1.93 \mathrm{bcd}$ & $0.99 \mathrm{de}$ & $2.23^{\mathrm{d}-\mathrm{h}}$ & 2.21 \\
\hline & & 2.7 & $2.64^{\mathrm{abc}}$ & $1.28^{\mathrm{a}-\mathrm{d}}$ & $3.59 \mathrm{bc}$ & 2.63 \\
\hline & 5 & 0 & $2.82^{\mathrm{b}}$ & $1.00 \mathrm{de}$ & $2.55^{\mathrm{b}-\mathrm{g}}$ & 2.02 \\
\hline & & 1.8 & $2.77 \mathrm{abc}$ & 0.93 de & $1.09 \mathrm{~h}$ & 1.49 \\
\hline & & 2.7 & $2.37 \mathrm{bc}$ & 0.93 de & $2.70^{b-f}$ & 2.06 \\
\hline \multirow[t]{9}{*}{35} & 1 & 0 & $2.52^{\mathrm{abc}}$ & $1.55^{\mathrm{ab}}$ & $2.54^{\mathrm{b}-\mathrm{g}}$ & 0.90 \\
\hline & & 1.8 & $2.48^{c}$ & $1.61^{\mathrm{a}}$ & $3.76^{\mathrm{b}}$ & 2.32 \\
\hline & & 2.7 & $2.70^{a b c}$ & $1.54^{\mathrm{ab}}$ & $1.75^{\mathrm{f}-\mathrm{h}}$ & 1.18 \\
\hline & 3 & 0 & $2.12^{\mathrm{bcd}}$ & $0.81 \mathrm{e}$ & $1.50^{\text {fgh }}$ & 1.33 \\
\hline & & 1.8 & $2.54^{\mathrm{abc}}$ & 0.88 de & $2.39 \mathrm{c}-\mathrm{g}$ & 2.17 \\
\hline & & 2.7 & $2.43^{a b c}$ & $1.11^{\mathrm{b}-\mathrm{e}}$ & $2.22^{\mathrm{d}-\mathrm{h}}$ & 1.75 \\
\hline & 5 & 0 & $2.27 \mathrm{bc}$ & 1.06 cde & $3.26 \mathrm{bcd}$ & 3.52 \\
\hline & & 1.8 & $0.88^{\mathrm{d}}$ & $0.88^{\mathrm{de}}$ & $2.61^{\mathrm{b}-\mathrm{g}}$ & 2.34 \\
\hline & & 2.7 & $2.26^{b c}$ & $1.12^{\mathrm{b}-\mathrm{e}}$ & $2.75^{b-f}$ & 2.82 \\
\hline
\end{tabular}

Figures in column under each factor of treatment having the same letter or without letter do not differ significantly whereas figures with dissimilar letter(s) differ significantly as per DMRT 
It can be concluded that the highest LAI and CGR were found in older tiller seedling by transplanting 5 tiller seedlings hill-1 fertilized with 1.8g USG. The highest RGR and NAR were obtained in younger tiller seedling by transplanting single seedling hill-1 ${ }^{-1}$ ertilized with $1.8 \mathrm{~g}$ USG per four hills of every alternate row.

\section{REFERENCES}

El-zahab, A. A. A., Asore, A. M. and Al-Hadeedy, K. H. 1980. Comparative analysis of growth, development and yield of five bean cultivars (Vicia faba L). Z. Acker- und Planzenbau, 149: 1-13. [CAB Abst., 1980-1983].

Haloi, B. and Baldev, A. 1986. Effect of irrigation on growth attributes in chickpea, when grown under different dates of sowing and population pressure. Indian J. Plant Physiol., 29: 14-27.

Hanada, K. 1979. Differentiation and development of tiller buds in rice plants. J.A.R.Q., 16:79-86.

Hossain, M. A., Sarkar, M. A. R. and Paul, S. K. 2011. Growth analysis of late transplant aman rice (cv. BR 23) raised from tiller seedlings. Libyan Aric. Res. Cen. J. Intl., 2(6): 265-273.

Hunt, R. 1978. Plant Growth Analysis. Study in Biology No.96. Edward Arnold, London. pp. 27-30.

Inge, J. S., Fleack. K., Nackaerts, B., Muys, P., Coppin, M. W. and Baret, F. 2004. Review of methods for in situ leaf area index determination. Agric. For. Meteorol., 121: 19-35.

Karim, M. M. and Siddique, K. A. M. 1991. Crop growth and relative growth rates of old and modern wheat cultivars. Aust. J. Agril. Res., 42(1): 13-20.

Langer, R. H. M. 1979. Tillering. In: how grasses grow (2nd ed.). Studies in Biology. No. 34, Edward Annold, London. p. 67.

Mansab, A. L., Jeffers, D. L. and Henderlong, P. R. 2003. Interrelationship between leaf area, light interception and growth rate in soybean-wheat system. Asian J. Plant Sci., 2: 605-612.

Mridha, M. A., Nasiruddin, J. M. and Siddique, S. B. 1991. Tiller separation on yield and area covered in rice. Proc. of the $16^{\text {th }}$ Ann. BAAS conf. held on 5-7 July 191, Dhaka. pp. 67.

Nishikawa, G. and Hanada, K. 1951. Studies in branching habit in crop plants. I. On the differentiation and development of tillering buds in low land rice seedling grown under different seeding space. Proc. Crop Sci. Soc. Japan., 28: 191-193.

Patterson, D. T. 1982. Effects of lights and temperature on weed/crop growth and competition. In: Biometerology in integrated pest management (Eds: J. L. Hetfield and I. J. Thomason). Academic press, New York. pp. 407-420.

Radford, P. J. 1967. Growth analysis formulae, their uses and abuses. Crop Sci., 7: 171-175.

Samba, T., Stephen, C., Alex, A. R., Martin, D., Mortensen, A. and Spotanski, J. J. 2003. Velvet leaf interference effect on yield and growth of grain shorghum. Agron., J., 95: 1602-1607.

Sarkar, M. A. R., Paul, S. K. and Hossain, M. A. 2011. Effect of row arrangement, age of tiller seedlings and number of tiller seedlings hill ${ }^{-1}$ on performance of transplant Aman rice. J. Agril. Sci., 6(2): 59-68. 
Sarkar, M. A. R., Paul, S. K. and Ahmed. M. 2002. Effect of row arrangement and tiller separation on the growth of transplant aman rice. Pakistan J. Biol. Sci., 5(4): 404-406.

Shipley, P. 2006. Net assimilation rate, specific leaf area and leaf mass ratio: which is most closely correlated with relative growth rate, A meta-analysis, Fun. Ecol., 20: 565-574.

Siddique, S. B., Mazid, M. A., Mamun, M. A., Ahmed, K. U., Jabbar, M. A., Mridha, A. J., Ali, M. G., Chowdhury, A. A., Roy, B. C. Hafiz, M. A., Biswas J. C. and Islam, M. S. 1991. Cultural practices for modern rice cultivation under low land ecosystems. Proceedings of workshop on experiences with modern rice cultivation in Bangladesh held in 23-25 April, 1991 at BRRI, Gazipur.

Sonnetag, O., Chen J. M. and Roulet, N. T. 2007. Using direct and indirect measurements of leaf area index to characterize the shrub canopy in an ombrotophic peatland. Agric. For. Meteorol., 144: 200-212.

Tanaka, A. 1983. Physiological aspects of productivity. In: Potential productivity of yield of crops under different environments. IRRI, Los Banos, Philippines.

Tsuni, Y. and Fujisi, K. 1965. Studies on the dry matter production of sweet potato: Crop Science Society of Japan Proceeding, 33, 230-235 (cited by V. Ravi and P. Indira) in. Hort. Rev., 23: 277-316.

Welles, J. M. 1990. Some indirect methods of estimating canopy structure. Rem. Sens. Rev., 5: 31-43.

Wilson, J. H. and Ellis, R. D. 1981. Supply of dry matter from stem and seed in rice grown under dry land conditions. Intl. Rice Res. Newsl., 6(1): 23-24.

Yoshida, S. 1981. Physiological Analysis of Rice Yield. In: "Fundamentals of Rice crop Science”. p. 269. Intl. Rice Res. Ins., Los Banos, Philippines. 